\title{
遺伝性肝炎（LEC）ラットに出現する 巨大肝細胞の核 DNA の解析
}

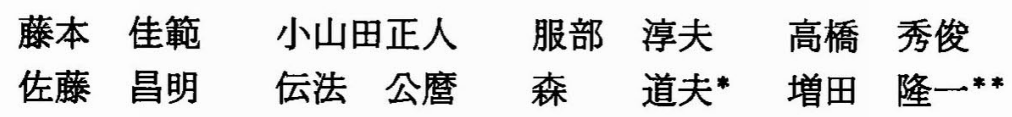

はじめに：遗伝性肝炎 (Long-Evans with a cinnamon-like coat color : LEC) ラット1は, 最近開発 樹立された疾病モデル動物である. 生後約 4 カ月にな ると何の誘因もなく突然, 黄㾞を発現し, 約 1 週間以 内に半数が肝不全で死亡する. 残りの半数は肝炎から 徐々に回復し， 1 年以上長期生存した個体には, 高率 に肝癌が発生する。このように LECラットはヒトの 劇症肝资，及び肝炎から肝癌へ進展する過程を研究す る上で, 有用なモデル動物である.

この LEC ラットにみられる肝炎の組織学的特徵 は, 肝細胞の核と細胞質の著しい巨大化であるが, 超 枚構造的には異常な物質の蓄積は認められない22. 肝 炎の初期に肝細胞の細胞分裂像がみられるにもかかわ らず，肝細胞の巨大化が目立つことから，細胞分裂の 過程になんらかの障害が起こっている可能性が考光ら れる. 今回, 我々は肝咨発症時の巨大肝細胞について propidium iodideを用いた flow cytometryにより, 核 DNA 量を測定し，䀒細胞の巨大化の原因について 検討した.

材料および方法：1. 動物：LEC ラットは北海道大 学実験生物センターげっ歯飼育部で開発樹立され, 近 交系で維持されている Long-Evans 系ラットで, 生後 5 カ月齢の肉眼的に黄疸を呈したラット5匹(雌 3 匹, 雄 2 匹）を用いた。

2. 方法: 肝細胞の分離は collagen digestion method $^{3}$ K, 核 DNA の染色は detergent-trypsin method $^{4}$ に従った。 まず, collagenaseにより分離浮遊 した肝細胞をDMSO と trypsinにより裸核とし， propidium iodideにより染色した，核DNA 量の測定 には flow cytometry EPICS.C を用いた。光影用標本 は, 同一ラットについて肝細胞分離前に肝左外側葉を 切除し, Carnoy 液で固定した。なお, 対照としては,

* 札幌医科大学病理学教室

** 北海道大学理学部染色体研究所

〈受付日63年 3 月 9 日 $>$
LEC と同時に分離されながらす肝炎を発症しない Long-Evans with an agouti-coat color (LEA) ラッ トを用いた。

結果：黄疸を呈した 5 カ月齢のラットは，ほ注同様 の肝組織像及び核 DNA 量を示したので，そのうちの 1 匹の結果を提示する.

1. 肝組織所見：小葉構造の著しい乱れは認められ ないが，肝細胞の核と細胞質に著しい巨大化が認めら れ，一部の巨大核には偽封入体も存在した。好酸性の 斑状壊死に陥った肝細胞や，胆汁や赤血球を食食した Kupffer 細胞が認められたが, 炎症細胞浸潤は軽度で あった（Fig. 1)，小葉周辺には偽胆管や，胆管上皮様 の細胞“oval cell”, 小型の再生肝細胞の増生が認めら れた。

2. Flow cytometry による核 DNA 量の測定：上 記の組織像を示す肝から得られた細胞の核 DNA 量を 測定した. Fig. 2a はその核 DNA 量のヒストグラム であるが, 各ピークはほぼすべて2nの指数倍領域にの

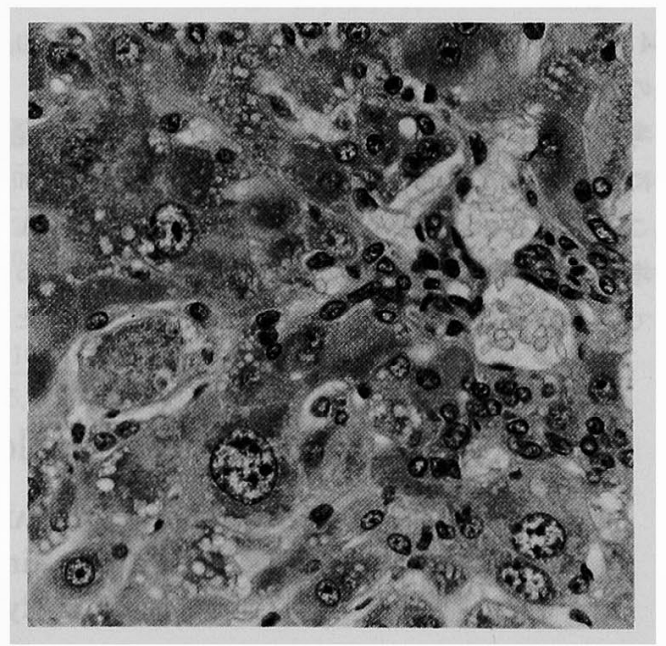

Fig. 1 Histology of the liver of 5 month-old LEC rat. Many enlarged hepatocytes with large nuclei are observed. 

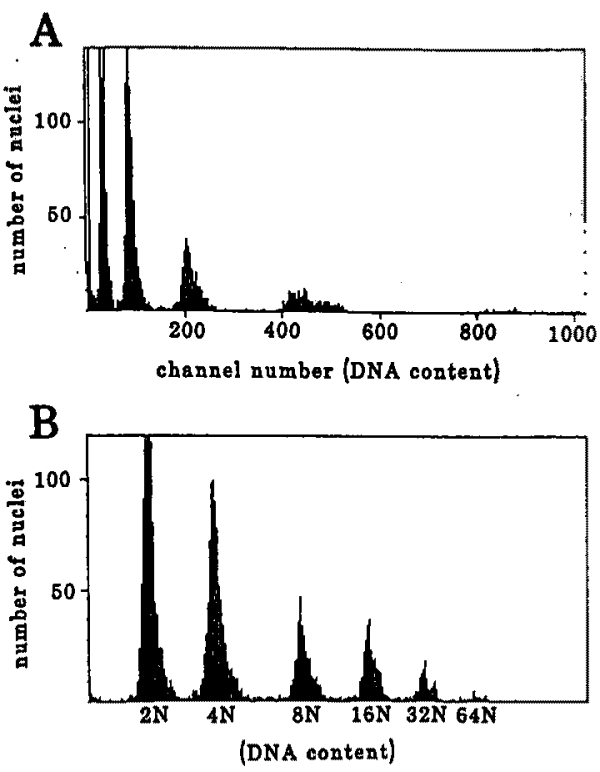

Fig. 2 DNA histograms of liver nuclei of 5 monthold LEC rat. B; DNA histogram transformed to logarithms.

み存在した。 このヒストグラムを対数に变換すると， Fig. 2bのように2n, 4n, 8n, 16n, 32n, 64n での各 polyploid Kピークが存在する多峰性のヒストグラム がえられた。各 polyploid の核の比率は2n-40.6\%, 4n $-29.5 \%, 8 n-13.0 \%, 16 n-10.7 \%, 32 n-4.9 \%, 64 n$ -1.3\%であった。 また，核 DNA 量は核の大きさに相関 して增加していた，同月龄のLEA ラットでは2n $-34.6 \%, 4 n-62.2 \%, 8 n-3.1 \%, 16 n-0.1 \%$, それ以 上の polyploidはみられなかった。

考察: 今回の実驗結果上り, LEC ラットの肝癷発症 時に出現する肝細胞の巨大核では，DNA 量の増加が 起こっていることが明らかとなった。 そして, DNA 量 の増加は aneuploidy ではなく， polyploidyによるも ので，非常に高いクラス $(-64 \mathrm{n})$ ぬで出現することが
分かった。

正常ラット肝細胞の polyploidy は, 生理的には老化 に伴って出現し，また実験的には，2/3部分肝切除など による著しい增殖刺激を加えた場合に認められてい る5)。しかし，それらの場合，DNA 量はせいぜい16n位 程度であり，肝炎発症時の LEC 肝に゙見られるょらな 著しい, polyploidyは，非常に稀な現象である.

これまで, polyploidy が出現する機序としては，(1) DNA 合成期 ( $\mathrm{S}$ 期)を経て細胞分裂期 (M 期) に入る が，細胞質分筡が起こらず，2核細胞が形成され，引 き続いて 2 核細胞の核の融合が起こったり，あるいは M 期の telophase に括いて染色体の融合が起こるた めに, polyploidy が形成される可能性，（2）S期を経 るものの，M期に入れず， polyploidy の形成される可 能性などが考えられている. LEC ラットの肝細胞にお いては, 肝资の発症に先立ち 2 核細胞の有意の増加台 観察されており，細胞質分裂の障害による2核細胞の 增加が polyploidy の出現に重要な役割をしていると 考えられる。

LECラットに拈ける肝炎発症の原因は不明である が，単一遗伝子に支配され，常染色体劣性遺伝に従5 ことが明らかにされている6 . 今回は 5 カ月龄のデー タのみを示したが, LECラット肝では生後ますなく り, polyploidの出現がみられる（未発表データ）こと より，細胞周期の異常が肝炎発症と密接に関連してい る可能性すすり，LEC ラット肝細胞の増殖因子への反 応性を含めて，現在検討中である。

卖引用語：肝炎モデル動物, DNA, flow cytometry 文 献：1) Yoshida MC, et al：J Hered 78: 1987(in press) 2) 伝法公麿, 他：日本毒性病理会誌 1988 (in press) 3) Berry $M$, et al: J Cell Biol 63:506 $-520,1969$ 4) Vindel $\phi \mathrm{v} L L$, et al: Cytometry 3 : $323-327,1983$ 5) 松田健志, 他：肝贜 27 ： 1303-1312, 1986 6) Masuda R, et al : Lab Anim (in press)

\title{
DNA analysis of megalocytic hepatocytes in LEC rats
}

\author{
Yoshinori FujImoto, Masahito Oyamada, Atsuo Hattori, Hidetoshi TaKaHashi, \\ Masaaki SATOH, Kimimaro DEMPO, Michio MORI* \\ and Ryuichi MASUDA**
}

\footnotetext{
* Department of Pathology, Sapporo Medical College (Sapporo)

** Chromosome Research Unit, Faculty of Science, Hokkaido University (Hokkaido)
} 